\title{
STATE OF THE ART REVIEW ON UTILIZATION OF QUARRY WASTE REPLACEING FINE AGGREGATE IN CONCRETE
}

\author{
Patel Kirtan $\mathbf{R}^{1}$, Siddharth Shah ${ }^{2}$ \\ ${ }^{1} P G$ Student, Marwadi Education Foundation, Gujarat, India \\ ${ }^{2}$ HOD, Civil Engineering Department, Marwadi Education Foundation, Gujarat, India
}

\begin{abstract}
Concrete is most widely used material in construction industries and day by day the usage of fine aggregate in concrete has become challenge due to environmental problems. In this paper an attempt is made to reveal the facts and figure to utilize the quarry waste materials in concrete replacing fine aggregates. The quarry waste has very similar physical and chemical properties as river sand and they can be good substitute to natural river sand as fine aggregates. The quantity of waste produced is also very large to suffice the need of the construction industry for its potential use in concrete. The literature review reveals that quarry waste alone is used for its potential use in concrete. In this study detailed review is carried out for various doses for maximum strength and economy is carried out in various sections. After critical review it was found that there is very little work on durability aspects of concrete prepared by quarry waste in combination with other wastes.
\end{abstract}

Keywords: Waste utilization, improved concrete, Sand replacement, Quarry waste $* * *$

\section{INTRODUCTION}

Due to the recent spurt in construction activity brought on by the current economic boom, the cost of construction has been increasing by up to $15 \%$ every year, a major factor for this escalation in costs is the price of raw materials like cement, steel, timber, aggregates etc. Increasing extraction of natural sand from river beds causing many problems, loosing water retaining sand strata, deepening of the river courses, causing bank slides, loss of vegetation on the bank of rivers, exposing the intake well of water supply schemes, disturbs the aquatic life as well as affecting agriculture due to lowering the underground water table etc are few examples. Now a day the natural sand can decrease the quantity and the river bed is nearly finished. It is Loss of Environment. The various state governments has ban on sand excavation. It is a big problem of construction Industry. Now days the quarry waste is used in mortar, precast jellies and finishing of road pavement. The researchers are research on fine replacement of sand with Quarry waste. In India Annual production of quarry waste is 20 MT (CPCB Data). The quarry waste production in Gujarat is $0.2 \mathrm{MT}$ (CPCB Data).

\subsection{Quarry Waste Production \& Properties}

About 20 to 25 per cent of the total production in each crusher unit is left out as the waste material-quarry waste. It is in the form of powder. The size of quarry waste is below than 90 micron. The quarry waste is dependent on location. The figure 1 showing Image of quarry waste produced at crushing unit.

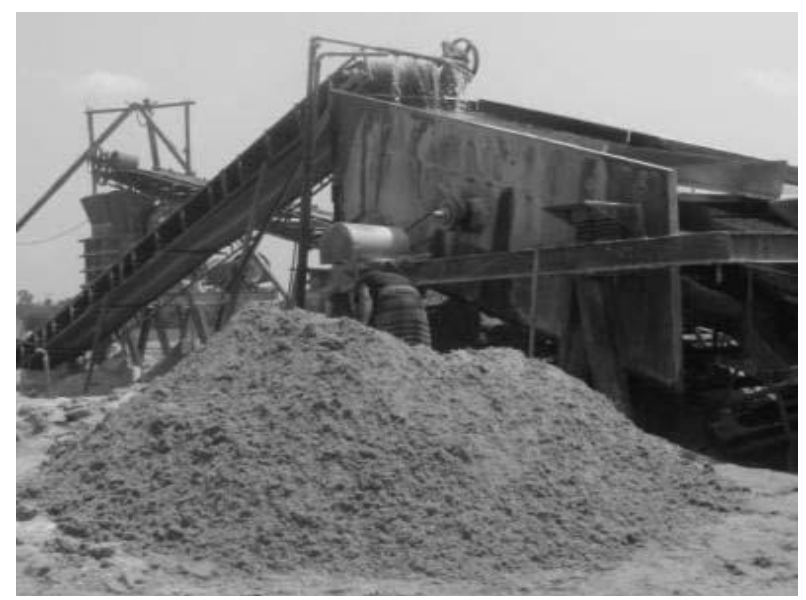

Fig 1.1 Crushing Unit producing quarry waste (A. A. Masrur Ahmed, 2010)

Table 1.1 Physical Properties of quarry waste

\begin{tabular}{|l|l|l|}
\hline Sr. No & Properties & Quarry waste \\
\hline 1 & Specific gravity & 2.54 \\
\hline 2 & Bulk density Kg/m ${ }^{3}$ & 1735 \\
\hline 3 & Water Absorption $\%$ & 1.20 \\
\hline 4 & Moisture content $\%$ & Nil \\
\hline 5 & Sieve analysis & FM= 2.5, Zone 2 \\
\hline
\end{tabular}

Table 1.2 Chemical properties of quarry waste

\begin{tabular}{|l|l|l|}
\hline Sr. No & Chemical Composition & Percentage \\
\hline 1 & Silica & 62.80 \\
\hline 2 & Aluminum dioxide & 18.72 \\
\hline 3 & Ferric Oxide & 6.54 \\
\hline 4 & Magnesium dioxide & 2.56 \\
\hline 5 & Calcium dioxide & 4.83 \\
\hline 6 & Sodium oxide & Nil \\
\hline 7 & Potassium oxide & 3.18 \\
\hline
\end{tabular}




\begin{tabular}{|l|l|l|}
\hline 8 & Titanium oxide & 1.21 \\
\hline 9 & Loss of Ignition & 0.48 \\
\hline
\end{tabular}

\subsubsection{Physical and Chemical Properties of Quarry Waste}

The Physical properties of quarry waste are shown below. The table 1.1 shows the Physical properties of quarry waste.

\subsection{Review of Quarry Waste replacing Fine}

\section{Aggregate}

V Bhikshma R, R Kishore and N H M Raju [1] used 0\%, $25 \%, 50 \%, 75 \%$ and $100 \%$ replacement of sand with quarry waste. The $25 \%$ replacement of sand with quarry waste increase $3 \%$ in compressive strength at 28 days. The $50 \%$ replacement of sand with quarry waste increase $10 \%$ in compressive strength at 28 days. The $75 \%$ replacement of sand with quarry waste increase $17 \%$ in compressive strength at 28 days. The $100 \%$ replacement of sand with quarry waste increase $22 \%$ in compressive strength at 28 days.

V Syam Prakash, Dhanya Krishna N and G Jeenu [2] used $20 \%, 40 \%, 60 \%$ and $80 \%$ replacement of sand with quarry waste. The 28 days compressive strength of $\mathbf{M i x}_{220}$ decreases $20.28 \%$ from 28 days compressive strength of Mix 200. The 28 days compressive strength of $\mathbf{M i x}_{240}$ decreases $17.35 \%$ than 28 days compressive strength of Mix $_{200}$. The 28 days split tensile strength of Mix ${ }_{160}$ increases $0.90 \%$ than 28 days split tensile strength of $\operatorname{Mix}_{100}$. The 28 days split tensile strength of $\mathrm{Mix}_{260}$ decreases $3.41 \%$ from 28 days compressive strength of $\mathrm{Mix}_{200}$.

Sudhir S Kapgate and S R Satone [3] used 0\%, 20\%, 25\%, $30 \%, 35 \%$ replacement of sand with quarry waste. The $35 \%$ replacement of sand with quarry waste in M25 grade concrete increases $1.38 \%$ in compressive strength at 28 days. The $35 \%$ replacement of sand with quarry waste in M25 concrete increases $30.48 \%$ in split tensile strength at 7 days. The $35 \%$ replacement of sand with quarry waste in M25 grade of concrete decreases $18 \%$ in split tensile strength at 14 days. The $35 \%$ replacement of sand with quarry waste in M25 concrete decreases $20.37 \%$ in split tensile strength at 28 days.

Dr P B Sakthivel, C Ramya and M raja [9] used 0\%, 10\%, $20 \%, 30 \%, 40 \%$ replacement of sand with quarry waste. The Author has made $S_{90} D_{10}, S_{80} D_{20}, S_{70} D_{30}$ and $S_{60} D_{40}$ for compressive strength, split tensile strength and flexure strength. The $10 \%$ replacement of sand with quarry waste $10 \%$ improved compressive strength at 28 days. The $20 \%$ replacement of sand with quarry waste decreases $22.4 \%$ compressive strength at 28 days. The $10 \%$ replacement of sand with quarry waste is increases $23 \%$ compressive strength at 28 days. The $20 \%$ replacement of sand with quarry waste increases $19 \%$ split tensile strength at 28 days. The $10 \%$ replacement sand with quarry waste increases $12 \%$ flexure strength at 28 days. The $20 \%$ replacement of sand with quarry waste improved $6 \%$ flexure strength at 28 days.
Table 1.3 Review of quarry waste replacing fine aggregate

\begin{tabular}{|l|l|l|}
\hline Author & $\begin{array}{l}\text { Per } \\
\text { replace }\end{array}$ & Significant contribution \\
\hline $\begin{array}{l}\text { V } \\
\text { Bhikshma }\end{array}$ & $\begin{array}{l}0 \%- \\
100 \%\end{array}$ & $\begin{array}{l}\text { At 30\% replacement of sand } \\
\text { with Quarry Waste improved } \\
\text { by 10\% compressive strength }\end{array}$ \\
\hline $\begin{array}{l}\text { V Syam } \\
\text { Prakash }\end{array}$ & $\begin{array}{l}0 \%- \\
80 \%\end{array}$ & $\begin{array}{l}\text { At 20\% replacement of sand } \\
\text { with quarry Waste improved } \\
3.85 \% \text { compressive strength }\end{array}$ \\
\hline $\begin{array}{l}\text { Sudhir S } \\
\text { Kapgate }\end{array}$ & $\begin{array}{l}0 \%- \\
\text { P B }\end{array}$ & $\begin{array}{l}\text { At 30\% replacement } \\
\text { of sand with quarry waste } \\
\text { improved 6.94\% compressive } \\
\text { strength }\end{array}$ \\
\hline $\begin{array}{l}\text { Dr } \\
\text { Sakthivel }\end{array}$ & $40 \%$ & $\begin{array}{l}\text { At 20\% replacement of sand } \\
\text { with quarry waste decrease } \\
20 \% \text { compressive strength }\end{array}$ \\
\hline $\begin{array}{l}\text { Radhikesh } \\
\text { P Nanda }\end{array}$ & $\begin{array}{l}0 \%- \\
100 \%\end{array}$ & $\begin{array}{l}\text { At 25\% replacement of sand } \\
\text { quarry waste gives similar } \\
\text { compressive strength }\end{array}$ \\
\hline $\begin{array}{l}\text { G } \\
\text { balamurgan }\end{array}$ & $\begin{array}{l}0 \%- \\
100 \%\end{array}$ & $\begin{array}{l}\text { At 20\% replacement of sand } \\
\text { with quarry waste improved } \\
8 \% \text { compressive strength }\end{array}$ \\
\hline $\begin{array}{l}\text { Lohani T K } \\
\text { Ilangovana }\end{array}$ & $\begin{array}{l}0 \%- \\
50 \%\end{array}$ & $\begin{array}{l}\text { At 30\% replacement } \\
\text { of sand with quarry waste } \\
\text { improved 5\% compressive } \\
\text { strength }\end{array}$ \\
\hline $\begin{array}{l}\text { At } 100 \% \text { replacement sand } \\
\text { with quarry waste improved } \\
10 \% \text { compressive strength }\end{array}$ \\
\hline
\end{tabular}

Radhikesh P Nanda, Amiya K Das, Moharana N C has [12] used $0 \%, 25 \%, 50 \%, 75 \%, 100 \%$ replacement of sand with quarry waste. The 28 days compressive strength of normal concrete is $35 \mathrm{~N} / \mathrm{mm}^{2}$. The $\mathrm{FC}_{25} 28$ day's compressive strength is similar to the normal concrete. The $\mathrm{FC}_{50} 28$ day's compressive strength decreases $3 \%$ than $\mathrm{FC}_{0}$. The 28 days Flexure strength of $\mathrm{FC}_{0}$ is $8.40 \mathrm{~N} / \mathrm{mm}^{2}$. The $\mathrm{FC}_{25} 28$ days Flexure strength is $8.01 \mathrm{~N} / \mathrm{mm}^{2}$. The $\mathrm{FC}_{50} 28$ days Flexure strength is $7.95 \mathrm{~N} / \mathrm{mm}^{2}$. The $\mathrm{FC}_{25}$ flexure strength decreases $4.76 \%$ at 28 days. The $\mathrm{FC}_{50}$ flexure strength decreases $2.85 \%$ at 28 days.

G balamurgan and Dr P Perumal [10] used $0 \%$ to $100 \%$ replacement of sand with quarry waste. The $0 \%$ replaced concrete gives $22.22 \mathrm{~N} / \mathrm{mm}^{2}$ at 28 days. The 28 days compressive strength decreases $2.02 \%$ at 28 days. The 28 days compressive strength of $20 \%$ replaced concrete improved $8.01 \%$. The 28 days compressive strength at $30 \%$ replaces improved $13.99 \%$. The 28 days $10 \%$ compressive strength improved $0.53 \%$ at $100^{\circ} \mathrm{C}$. The 28 days compressive strength of $20 \%$ replaced concrete improved $3.61 \%$ at $100{ }^{\circ} \mathrm{C}$. The 28 days compressive strength of $30 \%$ replaced concrete improved $4.18 \%$ at $100^{\circ} \mathrm{C}$.

Lohani T K, Padhi M and Dash K P [6] used 0\%, 20\%, 30\%, $40 \%$, 50\% replacement of Sand with Quarry waste. The $30 \%$ replacement of sand with quarry waste gives $0.845 \%$ compaction factor. The $30 \%$ replacement of sand with quarry waste increases $17.39 \%$ in compressive strength at 7 days. The $30 \%$ replacement of sand with quarry waste 
increases $11.47 \%$ in compressive strength at 28 days. The $30 \%$ replacement of sand with quarry waste increases $11.76 \%$ in compressive strength at 91 days. In this study $30 \%$ replacement of sand with Quarry waste improved 5\% compressive strength.

R. Ilangovana, N. Mahendrana and K. Nagamanib [11] used $0 \%$ and $100 \%$ replacement of sand with quarry waste. The M20 grade concrete gives $31 \mathrm{~N} / \mathrm{mm}^{2}$. The 28 days compressive strength of quarry waste improved $11.26 \%$. The $100 \%$ quarry waste improved $11.36 \%$ in M30 grade concrete. The $100 \%$ quarry waste improved $3.63 \%$ compressive strength in M40 grade concrete at 28 days. The M20 grade concrete gives $5.10 \mathrm{~N} / \mathrm{mm}^{2}$. The $100 \%$ quarry waste in M20 improved $25.49 \%$ in Flexure strength at 28 days. The $100 \%$ quarry waste M30 in improved $9.72 \%$ at 28 days. The $100 \%$ quarry waste in M40 improved $10.22 \%$ in flexure strength at 28 days.

\subsection{Review of Quarry Waste replacing Fine}

\section{Aggregate in Mortar/Masonry}

Mohaiminal Haque, Sourav Ray and H M A Mahzuz [5] used $0 \%, 30 \%, 70 \%$ and $100 \%$ replacement of sand with quarry waste. The 7 days compressive strength of $30 \%$ replacement of sand with quarry waste in mortar increases $1.79 \%$ from normal concrete. The 14 days compressive strength of $30 \%$ replacement of sand with quarry waste is increases $1.96 \%$ from normal concrete. The 28 days compressive strength of $30 \%$ replacement of sand with quarry waste is increases $5.50 \%$ from normal concrete. The 28 days cylinder compressive strength for $25 \%$ replacement of sand with quarry waste decreases $11.97 \%$ from normal mixture. In this study $30 \%$ replacement of sand with quarry waste improved $5.50 \%$ compressive strength.

Table 1.4 Review of sand replacement with quarry waste in mortar/masonry

\begin{tabular}{|l|l|l|}
\hline Author & $\begin{array}{l}\text { Per } \\
\text { replace }\end{array}$ & Significant contribution \\
\hline $\begin{array}{l}\text { Mohaiminal } \\
\text { Haque }\end{array}$ & $\begin{array}{l}0 \%- \\
100 \%\end{array}$ & $\begin{array}{l}\text { At 30\% replacement of sand } \\
\text { with Quarry Waste improved } \\
5.50 \% \text { compressive strength }\end{array}$ \\
\hline $\begin{array}{l}\text { S P S } \\
\text { Rajput }\end{array}$ & $\begin{array}{l}0 \%- \\
100 \%\end{array}$ & $\begin{array}{l}\text { At 100\% Replacement of Sand } \\
\text { With Quarry Waste Increase } \\
70 \% \text { Brick Masonry } \\
\text { Compressive Strength }\end{array}$ \\
\hline
\end{tabular}

S P S Rajput and M S Chauhan [8] used zero and full replacement of sand with quarry waste. The mortar cubes of $100 \%$ replacement of sand with quarry waste increase $54 \%$ compressive strength at 3 days. The mortar cubes of $100 \%$ replacement of sand with quarry waste increase $30 \%$ compressive strength at 7 days. The brick masonry wall of $105 \mathrm{~mm} * 225 \mathrm{~mm} * 445 \mathrm{~mm}$ dimension using $100 \%$ replacement of sand with quarry waste increase $30 \%$ compressive strength. In this study $100 \%$ Replacement of Sand with quarry waste is increase $70 \%$ brick masonry compressive strength.

\subsection{Various Authors have Research on}

\section{Replacement of Sand with Quarry Waste and}

\section{Cement Replace with GGBS in Concrete}

Venu Malagavelli and P N Rao [4] used 0\%, 5\%, 10\%, 15\%, $20 \%, 25 \%$ and $30 \%$ replacement of sand with quarry waste. The $30 \%$ replacement of sand with quarry waste increase $6.62 \%$ in compressive strength at 28 days. The $25 \%$ replacement of sand with Robo sand and 50\% replaced ggbs increases $7.38 \%$ compressive strength at 7 days. The $30 \%$ replacement of sand with Robo sand and 50\% replaced ggbs increases $5.70 \%$ compressive strength at 7 days.

Table 1.5 Review of sand replace with Quarry waste and cement replace with GGBS

\begin{tabular}{|l|l|l|}
\hline Author & $\begin{array}{l}\text { Per } \\
\text { replace }\end{array}$ & \multicolumn{1}{|l|}{ Significant contribution } \\
\hline $\begin{array}{l}\text { Venu } \\
\text { Malagavelli }\end{array}$ & $0 \%-$ & $\begin{array}{l}\text { At 30\% replacement of sand } \\
\text { with quarry waste and 50\% } \\
\text { Replacement of cement with } \\
\text { ggbs Improved } \\
\text { compressive strength }\end{array}$ \\
\hline
\end{tabular}

\subsection{Review of Research on Sand Replaces with}

\section{Quarry Waste and Cement Replace with Fly Ash}

Chandana Sukesh, Katakam Bala Krishna, P Sri Lakshmi Sai Teja and S Kanakambara Rao [7] used 0\%, 10\%, 20\%, $30 \%, 40 \%$ and $50 \%$ replacement of sand with quarry waste. The $30 \%$ replacement of sand with quarry waste and water cement ratio 0.5 gives $30 \mathrm{~cm}$ slump. The $20 \%$ replacement of sand with quarry waste is increase $6.69 \%$ compressive strength at 28 days. The $50 \%$ replacement of cement with Fly ash is increase $6 \%$ compressive strength at 28 days compares to ordinary concrete. In this study $20 \%$ replacement of sand with quarry waste improved $6.69 \%$ compressive strength.

Table 1.6 Review of research on sand replacement with quarry waste and fly ash

\begin{tabular}{|l|l|l|}
\hline Author & $\begin{array}{l}\text { Per } \\
\text { replace }\end{array}$ & Significant contribution \\
\hline $\begin{array}{l}\text { Chandana } \\
\text { Sukesh }\end{array}$ & $\begin{array}{l}0 \%- \\
50 \%\end{array}$ & $\begin{array}{l}\text { At 50\% replacement of sand with } \\
\text { quarry waste and cement } \\
\text { replacement with fly ash } \\
\text { improved 5\% compressive } \\
\text { strength }\end{array}$ \\
\hline $\begin{array}{l}\text { Akshay } \\
\text { C. Sankh }\end{array}$ & $\begin{array}{l}0 \%- \\
\text { The combination of quarry waste } \\
\text { and fly ash reduction in cement } \\
\text { consumption, increased sulfate } \\
\text { resistance, increased resistance to } \\
\text { ASR and decreased permeability }\end{array}$ \\
\hline
\end{tabular}

Akshay C. Sankh, Praveen M. Biradar, Prof. S. J Naghathan and Manjunath B. Ishwargol [15] says that 20 to 25 percentage of the total production of crushing unit is left out as quarry waste. The $55 \%$ to $75 \%$ replacement of sand with quarry waste improved compressive strength. The combination of quarry waste and fly ash reduction in cement 
consumption, increased sulfate resistance, increased resistance to ASR and decreased permeability. However, the use of fly ash leads to a reduction in early strength of concrete. Therefore, the concurrent use of quarry dust and fly ash in concrete will lead to the benefits of using such materials being added and some of the undesirable effects being negated

\subsection{Review of Research on Sand Replacement with}

Quarry Waste, granulated Blast Furnace Slag and

\section{Granite Basalt Fine Quarry Residue.}

Medhat S. El-Mahllawy [13] used 50\% kaoline fine quarry residue, (10-40) \% granulated blast furnace slag, (10-40) \% granite basalt fine quarry residue. The Author has made $S_{1}$, $S_{2}, S_{3}, S_{4}, S_{5}$ batch for finding Acid resistance brick. The $S_{1}$ compressive strength at $1125^{\circ} \mathrm{C}$ is $660 \mathrm{~N} / \mathrm{mm}^{2}$ at 28 days. The $\mathrm{S}_{2}$ compressive strength at $1125^{\circ} \mathrm{C}$ is improved $7.5 \%$ at 28 days. The S3 compressive strength at $1125^{\circ} \mathrm{C}$ is improved $2.27 \%$ at 28 days. The $\mathrm{S}_{4}$ compressive strength is decreases $0.75 \%$ at 28 days. The $S_{5}$ compressive strength is decreases $28.33 \%$ at 28 days. The water absorption of $S_{1}$ is $0.50 \%$. The water absorption of $S_{2}$ is $0.48 \%$ loss. The water absorption of $\mathrm{S}_{3}$ is increases $0.02 \%$ from $\mathrm{S}_{1}$. The water absorption of $\mathrm{S}_{4}$ is increases $0.41 \%$ from $\mathrm{S}_{1}$. The water absorption of $S_{5}$ is $7.24 \%$. The acid weight loss of $S_{1}$ at 56 days is $0.15 \%$. The acid weight loss of $S_{2}$ is $0.06 \%$, which is lower than $S_{1}$. The acid weight loss of $S_{3}$ is 0.18 , which is $0.03 \%$ higher than $S_{1}$. The acid weight loss of $S_{4}$ is $0.25 \%$, which is $0.10 \%$ higher than $S_{1}$. The acid weight loss of $S_{5}$ is $0.48 \%$, which is $0.33 \%$ higher than $S_{1}$.

Table 1.7 Review of Research of sand replace with quarry waste, granulated blast furnace slag and granite basalt fine quarry residue.

\begin{tabular}{|l|l|l|}
\hline Author & $\begin{array}{l}\text { Per } \\
\text { replace }\end{array}$ & Significant contribution \\
\hline Medhat S. & $\begin{array}{l}0 \%- \\
\text { El- }\end{array}$ & $\begin{array}{l}\text { At 100\% replacement of sand } \\
\text { with 50\% quarry waste, 20\% }\end{array}$ \\
Mahllawy & $\begin{array}{l}\text { granite basalt fine quarry } \\
\text { residue and 30\% granulated } \\
\text { blast furnace slag improved } \\
7.5 \% \text { compressive strength }\end{array}$ \\
\hline
\end{tabular}

\subsection{Review of Research on Sand Replace with}

\section{Quarry Waste, Fly Ash and Billet Scale.}

Alaa A Shakir, Sivakumar Naganthan, Kamal Nasharudin Mustapha [14] used (10-15) \% cement, (50-60) \% quarry dust, (0-25) \% Fly ash and (0-25) \% Billet Scale. The Author has $\mathrm{A}_{1}, \mathrm{~A}_{2}, \mathrm{~A}_{3}, \mathrm{~A}_{4}, \mathrm{~A}_{5}, \mathrm{~B}_{1}, \mathrm{~B}_{2}, \mathrm{~B}_{3}, \mathrm{~B}_{4}$ and $\mathrm{B}_{5}$. The $\mathrm{A}_{1}$ concrete 28 days compressive strength is $22 \mathrm{~N} / \mathrm{mm}^{2}$. The $A_{2}$ concrete 28 days compressive strength is improved $11.36 \%$ from $A_{1}$. The $A_{3}$ concrete 28 days compressive strength is improved $19.54 \%$ from $\mathrm{A}_{1}$. The $\mathrm{A}_{4}$ concrete 28 days compressive strength is decreases $15.90 \%$ than $A_{1}$. The $A_{5}$ concrete 28 days compressive strength is decreases $65 \%$ than $A_{1}$. The $B_{1}$ concrete 28 days compressive strength is $10.60 \mathrm{~N} / \mathrm{mm}^{2}$. The $B_{2}$ concrete 28 days compressive strength is improved $16.98 \%$ from $B_{1}$. The $B_{3}$ concrete 28 days compressive strength is improved $51.60 \%$ from $B_{1}$. The $\mathrm{B}_{4}$ concrete 28 days compressive strength is decreases $13.20 \%$ from $\mathrm{B}_{1}$. The $\mathrm{B}_{5}$ concrete 28 day's compressive strength is decreases $41.60 \%$ from $B_{1}$. The Ultra sonic pulse velocity of $A_{1}$ is $3.51 \mathrm{Km} / \mathrm{s}$. The UPV of $A_{2}$ is decreases $7.40 \%$ than $\mathrm{A}_{1}$. The UPV of $\mathrm{A}_{3}$ is decreases $8.83 \%$ than $A_{1}$. The UPV of $A_{4}$ is decreases $27.63 \%$ than $A_{1}$. The UPV of $A_{5}$ is decreases $34.18 \%$ than $A_{1}$. The UPV of $B_{1}$ is 2.67 $\mathrm{Km} / \mathrm{s}$. The UPV of $\mathrm{B}_{2}$ is decreases $0.37 \%$ than $\mathrm{B}_{1}$. The UPV of $B_{3}$ is decreases $0.74 \%$ than $B_{1}$. The UPV of $B_{4}$ is decreases $10.11 \%$ than $B_{1}$. The UPV of $B_{5}$ is decreases $22.84 \%$ than $\mathrm{B}_{1}$.

Table 1.8 Review of Research of sand replaces with quarry waste, fly ash and billet scale

\begin{tabular}{|l|l|l|}
\hline Author & $\begin{array}{l}\text { Per } \\
\text { replace }\end{array}$ & Significant contribution \\
\hline $\begin{array}{l}\text { Alaa } \\
\text { A }\end{array}$ & $\begin{array}{l}0 \%- \\
100 \%\end{array}$ & $\begin{array}{l}\text { At 100\% replacement of sand with } \\
\text { Shakir }\end{array}$ \\
& $\begin{array}{l}\text { and } 12.5 \% \text { quarry waste, 12.5\% fly ash } \\
7.5 \% \text { compressive strength }\end{array}$ \\
\hline
\end{tabular}

\section{DISCUSSION}

Up to $20 \%$ to $35 \%$ replacement of sand with quarry waste can improve $8 \%$ compressive strength at 28 days. The $50 \%$ replacement of sand with quarry waste is decrease $3 \%$ compressive strength at 28 days. Up to $20 \%$ replacement of sand with quarry waste improves $20 \%$ split tensile strength at 28 days. The $30 \%$ to $40 \%$ replacement of sand with quarry waste decrease $20 \%$ split tensile strength at 28 days. Up to $20 \%$ replacement of sand with quarry waste improves $6 \%$ flexure strength at 28 days. The $25 \%$ to $50 \%$ replacement of sand with quarry waste is decrease $5 \%$ flexure strength at 28 days.

\section{CONCLUSION}

Based on the above literature review it could be concluded that particle replacement of sand with different alternative up to $30 \%$ replacement improved the compressive strength and in case of split tensile strength and flexure strength $20 \%$ replacement of sand is optimum. So the work above $30 \%$ is not good for strength criteria.

\section{REFERENCES}

[1]. V Bhikshma, R. Kishore and N. H. M. Raju (2010), "Flexural behavior of high strength Stone dust concrete", Challenges Opportunities and Solutions in Structural Engineering and Construction-Ghafoori (ed.), London, 9780-415-56809-8.

[2]. V. Syam Prakash, Dhanya Krishnan and G. Jeenu (2007), "Influence of fine stone dust on high strength concrete", 32 International Conference, Singapore.

[3]. Sudhir S. Kapgate and S. R. Satone (2013), "Effect of quarry dust as partial replacement of sand in concrete", Indian streams research journal 3(5), 2230-7850. 
[4]. Venu Malagavelli and P. N. Rao (2010)," High performance concrete with ggbs and Robo sand" International journal of engineering science and technology 2(10), 5107-5113.

[5]. Mohaiminul Haque, Sourav Ray H and M. A. Mahzuz (2012), "Use of Stone Powder with Sand in Concrete and Mortar: A Waste Utilization Approach", ARPN Journal of Science and Technology 2(7), 2225-7217.

[6]. Lohani T. K, Padhi M, Dash K. P and Jena S (2012), "Optimum utilization of Quarry dust as partial replacement of sand in Concrete", International Journal of Applied Sciences and Engineering Research 1(2), 2277-9442.

[7]. Chandana Sukesh, Katakam Bala Krishna, P Sri Lakshmi Sai Teja and S Kanakambara Rao (2013), "Partial Replacement of Sand with Quarry Dust in Concrete", International Journal of Innovative Technology and Exploring Engineering 2(6), 2278-3075.

[8]. S P S Rajput and M S Chauhan (2014), "Suitability of Crushed Stone Dust as Fine Aggregate in Mortars", International Journal of Emerging Technology and Advanced Engineering 4(3), 2250-2459.

[9]. Dr P b Sakthivel , C Ramya and M Raja, “An Innovative Method of replacing River sand by Quarry Dust waste in concrete for sustainability", International Journal of Scientific \& Engineering Research, Volume 4, Issue 5, 2013, ISSN 2229-5518.

[10]. G balamurgan and Dr P Perumal, "Use of Quarry Dust to replace sand in concrete - An Experimental Study", International Journal of Scientific and Research Publications, Volume 3, Issue 12, December 2013, ISSN 2250-3153.

[11]. R. Ilangovana, N. Mahendrana and K. Nagamanib, “ Strength and Durability properties of concrerte containing quarry Rock Dust As Fine Aggregate", Journal of IJSER, Volume 3, Issue 5, October 2008, ISSN 1819-6608.

[12]. Radhikesh P Nanda, Amiya K Das, Moharana N C, "Stone crusher dust as a fine aggregate in concrete for paving Blocks", Volume 1, No 3, 2010, ISSN 0976-4399.

[13]. Medhat S. El-Mahllawy, "Characteristics of acid resisting bricks made from quarry residues and waste steel slag", Construction and Building Materials 22, 2008, 18871896.

[14]. Alaa A Shakir, Sivakumar Naganathan, Kamal Nasharuddin Mustapha, "Properties of bricks made using fly ash, quarry waste and billet scale", Constuction and Building Material 41, 2013, 131-138.

[15]. Akshay C. Sankh, Praveen M. Biradar, Prof. S. J Naghathan, Manjunath B. Ishwargol, "Recent trends in replacement of Natural sand with different alternatives", IOSR journal of Engineering and civil Engineering, page 59-66, ISSN 2278-1684.

[16]. Gujarat Mineral Development Corporation Ltd (2002), "Gujarat District Geological Territory", Source Mineral Treasure of Gujarat.

[17]. Central Pollution Control Board (2007), "Comprehensive Industry Document Stone Crushers", Comprehensive Industry Document78.

\section{BIOGRAPHIES}

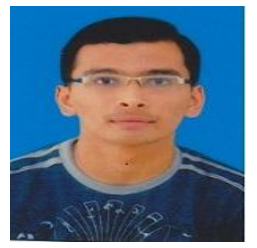

Patel kirtan Rohitbhai was born in 1992 in Modasa, Gujarat. He receives his Bachelor of Engineering degree in Civil Engineering from the Government Engineering College Dahod, Gujarat Technological University in 2013. At present he is Final year student of Master's degree in structural engineering from Marwadi Education Foundation Group of Institutions, Gujarat Technological University.

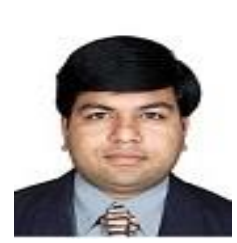

Dr Siddharth Shah is present at Associate Professor and Head of FOPG in Marwadi Education Foundation Rajkot. He has 9 Year Teaching and 5 Year Research Experience. He worked at NPCL Kakrapar Vyara and Kunal Construction

Surat. 